\title{
Análise da Experiência da Consciência na Religião do Judaísmo em Hegel, segundo Jean Hyppolite
}

\author{
Analysis of Consciousness Experience in the Religion of \\ Judaism in Hegel according to Jean Hyppolite
}

Claudemir da Silva ${ }^{1}$ Renato Kirchner ${ }^{2}$

\section{Resumo}

Analisando as experiências religiosas no pensamento hegeliano, podemos dizer que a religião judaica em sua experiência religiosa concebe Deus para além de si. Deus é algo distante, longe de ser alcançado pela consciência. Nisso consiste sua infelicidade, segundo a ótica hegeliana, pois Ele se revela para a consciência. Contudo, não é apreendido por ela, pois Ele está para além dela. Essa atitude de manter Deus distante da realidade efetiva, fez com que Hegel considerasse o povo judeu como o povo infeliz da história, porém, importante para que pudesse surgir uma outra forma de religião na história, o cristianismo. Se na religião do judaísmo Deus é experimentado fora do humano, no cristianismo Ele é experimentado no próprio homem, no Cristo encarnado.

Palavras-Chave: Hegel. Judaísmo. Cristianismo.

\begin{abstract}
Examining religious experience in Hegelian thought, we may state the Jewish religion, in its religious experience, conceives God beyond itself. God is something distant, far to be reached by the consciousness. Herein lies his unhappiness, according to the Hegelian view, for He reveals himself to consciousness, however, He is not apprehended by it, $\mathrm{He}$ is beyond it. This attitude of keeping God distant from actual reality, has helped Hegel consider the Jewish people to be the unhappy people in history, but, important to the emergence of another form of religion in history, Christianity. If in Judaism God is experienced outside the human, in Christianity He is experienced in man himself, in the incarnate Christ.
\end{abstract}

\footnotetext{
${ }^{1}$ Bacharel em Filosofia e Teologia pela Pontifícia Universidade Católica de Campinas. Mestre em Ciências da Religião pela PUC-Campinas.

2 Professor titular da Pontifícia Universidade Católica de Campinas. Membro do corpo docente permanente da Faculdade de Filosofia e do Programa de Pós-Graduação em Ciências da Religião.
} 
Religare, ISSN: 19826605, v.15, n.1, agosto de 2018, p.287-307.

Keywords: Hegel. Judaism. Christianity.

\section{Introdução}

A presente reflexão retrata a experiência religiosa da consciência dentro da religião do judaísmo ${ }^{3}$, segundo a perspectiva de Hegel. Tal experiência apresenta um Deus separado do humano, Ele está para além da consciência humana, totalmente transcendente. E, por isso, não pode ser alcançado pela consciência e, por não se tornar efetivo na consciência do povo judeu, Hegel nomina essa consciência como infeliz. Nas palavras de Hyppolite, “o povo judeu era o povo infeliz da história porque representava a reflexão total da consciência fora da vida" (HYPPOLITE, 1999, p. 206).

Para justificar essa tese, recorremos aos Escritos de juventude de Hegel (1978). Nestes escritos, Hegel refere-se a dois termos importantes para a compreensão daquilo que, mais tarde, na Fenomenologia do Espírito (2002), ele haveria de denominar como consciência infeliz. Para Hegel, a "consciência infeliz é a consciência de si como essência duplicada" (HEGEL, 2002, p. 159), homem e Deus. Tais termos são: separação (Trennung) e dominação (Herrschaft). Esses termos aparecem num conjunto de escritos que Hegel escreveu durante os anos de 1799-1800, denominado O espírito do cristianismo e seu destino. Esse escrito marca, para Hegel, aquilo que se tornou o paradigma

\footnotetext{
${ }^{3}$ Os textos reunidos sob o título O Espírito do cristianismo e seu destino foram redigidos por Hegel entre 1799 e 1800. Na primeira seção desses textos encontramos o seguinte título: Der Geistdes Judentuums. Como o título indica, esta parte trata da religião primitiva, do judaísmo, do mundo no qual nasce e vive Jesus. Empenhado de dar conta do que ele chama de "o espírito do judaísmo", Hegel sustenta que esse mundo não era o da unidade, da beleza e da felicidade, mas, antes, um mundo de oposições e divisões, um mundo no qual os homens viviam separados da natureza, de seu Deus, de seu Estado e de sua comunidade. Hegel inicia sua análise apoiando-se sob certo número de passagens-chave do Antigo Testamento. Objetiva dar conta da história espiritual do judaísmo que, segundo os termos do próprio filósofo, havia determinado o destino do povo judeu. Essa análise não só moldaria o destino do povo judeu, mas igualmente determinaria o conjunto da história do mundo ocidental depois da queda da República Helênica, da cidade grega. O espírito da Grécia, que, segundo ele, era o da unidade, da harmonia, da beleza e do amor, o judaísmo substituíra pelo espírito da separação, da divisão e das oposições. Segundo Hegel, essas situações vão se desenvolver no curso da história do Ocidente até o mundo moderno.
} 
Religare, ISSN: 19826605, v.15, n.1, agosto de 2018, p.287-307.

original da consciência infeliz. Para tanto, ele se reporta às experiências religiosas de dois personagens bíblicos, a saber, Abraão e Noé:

Com Abraão, o verdadeiro tronco dos judeus, começa a história deste povo; seu espírito é a unidade, a alma rege todos os destinos de seus descendentes [...] o rumo tomado pelo desenvolvimento da humanidade antes de Abraão, foi o importante período dos tempos de Noé (HEGEL, 1978, p. 234, tradução nossa).

Dentro dessa perspectiva, seguindo a lógica da narrativa bíblica, analisaremos numa ótica hegeliana a atitude de Noé (judeu) e a atitude de Deucalião e Pirra (mitologia grega) ${ }^{4}$. No primeiro caso, ao invés de reconciliarse com a natureza depois do dilúvio, Noé optou por dominá-la, submetendoa e a um ser mais poderoso (Deus), ao passo que Deucalião e Pirra, depois do dilúvio grego, convidaram os homens a reconciliarem-se com a natureza, pois “transpondo a natureza no pensamento e o pensamento na natureza, o povo hebreu não pode senão se opor incessantemente à natureza e à vida" (HYPPOLITE, 1999, p. 206).

A separação do divino com o humano, segundo Hegel, tem sua raiz no dilúvio (cf. Gn 7-9).Hegel sustenta que, depois do dilúvio, o povo judeu passou a considerar a natureza como uma grande inimiga e faria qualquer coisa para dominá-la.Ao assumir essa postura, acabaram por se separar da natureza, onde encontravam seus deuses; a natureza deixou de ser o lugar misterioso, sagrado e familiar, e passou a ser considerada algo que deveria ser dominado (Gn 9)5. Assim, a pedra, a planta, a madeira, perderam seu

\footnotetext{
${ }^{4} \mathrm{O}$ mito de Deucalião e Pirra faz referência ao dilúvio, presente em quase todas as religiões e que retrata a destruição do mundo devido à decadência dos valores humanos.

5 “Noé é uma figura importante não só no judaísmo e no cristianismo, mas também no islamismo. Sua aliança com Deus faz parte do Alcorão. A Torá também fala de uma aliança de Deus com todos os seres vivos. Deus fez essa aliança com Noé, cuja família sobreviveu ao dilúvio que acabou com quase toda a vida na Terra. A aliança estipulava que Deus jamais destruiria o mundo de novo. Como no caso dos patriarcas de Israel, Deus também prometeu a Noé muitos descendentes. O símbolo da aliança de Deus com Noé seria o arco-íris, que, a partir daquele momento, serviria como lembrete da promessa de segurança divina. Mais tarde, os estudiosos afirmaram que a aliança incluía sete leis, válidas para toda a humanidade. As 'sete leis de Noé'
} 
Religare, ISSN: 19826605, v.15, n.1, agosto de 2018, p.287-307.

caráter sagrado; para eles, esses elementos tornaram-se objetos de desprezo, ou seja, dessacralizaram o mundo sensível, deslocando o divino para a esfera suprassensível. Criaram, segundo Hegel, “um Deus irrepresentável e abstrato, um Deus ausente e, de toda sorte, escondido" (THIBODEAU, 2015, p. 44). Nesta mesma esteira, a atitude de Abraão, de deixar sua pátria em busca de uma descendência numerosa, fez com que rompesse os laços com sua tribo, tornando-se submisso a um Deus transcendente.

Também encontramos essa temática na Fenomenologia do Espírito (2002), no capítulo próprio sobre a "consciência infeliz", em que, ao experimentar Deus fora de si, persiste na sua infelicidade vivendo uma dicotomia entre o finito e o infinito, o além e o aquém, o homem e Deus. Nisso consiste a inadequação, na visão de Hegel, da concepção de Deus pelos judeus. Porém, Hegel diz que a religião do judaísmo foi essencial para a vinda de uma nova forma de religião, o cristianismo, que pela encarnação de Cristo, Deus se tornou presente, deixou de ser para além do homem e se tornou um com ele. No cristianismo, Deus se tornou também humano, a natureza divina é a mesma que a humana. Aquilo que na consciência do judaísmo está para além de si, no cristianismo está na consciência de si mesma.

\section{A separação entre o Divino e o Humano}

Segundo Ian Couliano e Mircea Eliade, “a composição do Gênesis é animada por um processo que inicialmente se prende à monolatria, mas que, mais tarde transformara-se em monoteísmo" (COULIANO e ELIADE, 1994, p. 219). Essa informação nos ajuda a entender a tese de Hegel de que, antes do dilúvio, o homem e a natureza viviam em perfeita harmonia, uma vez que

proibiam a idolatria, o assassinato, a blasfêmia, o roubo, a imoralidade sexual (como o incesto) e o consumo de determinadas carnes, e requeriam a criação de tribunais de justiça" (O LIVRO DAS RELIGIÕES, 2014, p. 125). 
Religare, ISSN: 19826605, v.15, n.1, agosto de 2018, p.287-307.

nos tempos mais remotos, "as forças divinas são as forças da natureza" (COULIANO e ELIADE, 1994, p. 231). Nesse sentido, recorremos também a Mircea Eliade, em especial à sua obra denominada Mito e realidade, pois segundo ele:

Os mitos relatam a constituição da condição humana. Essa condição tem uma história: certos eventos foram decisivos para determinados povos, e foi depois deles que o homem se tornou o que é atualmente. Essa história primordial, dramática e algumas vezes trágica, deve ser não só conhecida, mas também continuamente rememorada (ELIADE, 2013, p. $84)$.

Esse pensamento de Mircea Eliade nos ajuda a entender a leitura que Hegel faz da figura mítica de Noé acerca do evento catastrófico do dilúvio que devastou a terra naqueles tempos. Esse acontecimento, segundo Hegel, determinou a vida do povo judeu, levando-o ao total rompimento com a natureza. Assim, diz ele: “o dilúvio do tempo de Noé causou sobre as mentes dos homens uma profunda ruptura com a natureza e seu efeito não poderia ser outro que a descrença na natureza" (HEGEL, 1978, p. 234, tradução nossa).

Essa história, segundo Hegel, se impregnou na consciência coletiva dos descendentes de Abraão. Nessa ótica, o dilúvio marca o momento de uma profunda ruptura entre o homem e a natureza, e seu efeito foi a mais formidável perda da fé na natureza, pois o mundo no qual o judeu vivia era inteiramente divinizado antes do dilúvio, uma vez que o divino estava presente na natureza. Assim, ao romper com a natureza, concomitantemente, ele rompe com o divino. Os judeus, sustenta Hegel, passaram depois do dilúvio a considerar a natureza como uma potência irredutivelmente hostil e estranha e fariam de tudo para dominá-la:

Para que o homem pudesse resistir aos agressivos impactos desta natureza agora hostil, ela teria que ser dominada, e uma vez que o todo pode ser dividido apenas em ideia e na realidade, a unidade suprema de dominação encontra o bem em algo pensado e o bem em algo real (o ideal é real) (HEGEL, 1978, p. 235, tradução nossa). 
Religare, ISSN: 19826605, v.15, n.1, agosto de 2018, p.287-307.

Essa foi a forma que Noé encontrou para resistir aos fenômenos naturais, dominando a natureza. Para tanto, segundo a interpretação de Hegel, Noé transforma algo pensado em real por meio da aliança feita com Deus depois do dilúvio. Assim, diz Hegel:

Foi no [ser] pensamento que Noé reconstruiu o mundo destruído. Ele fez o seu ideal - algo que pensou - algo que existe e, em seguida, se opôs a ela todo o resto, [também] como algo pensado; ou seja, como algo dominado. Este ser lhe prometeu manter-se dentro dos limites dos elementos que lhe serviram de modo que nunca poderia ter outro dilúvio que destruísse a humanidade (HEGEL, 1978, p. 235, tradução nossa).

Essa estrutura de dominação e aliança encontramos no livro do Gênesis da seguinte forma: “Todos os animais da terra vos temerão e respeitarão. Quanto a vós, crescei e multiplicai-vos, povoai a terra e dominai-a. Eu faço uma aliança convosco e com vossos descendentes e não haverá outro dilúvio que devaste a terra" (cf. Gn 9).

De fato, afirma Hans Küng, “a aliança feita com Noé depois do dilúvio foi uma aliança com a criação inteira" (KÜNG, 2004, p. 190). Assim, ao fazer essa aliança com Deus, no entendimento de Hegel, Noé retirou o divino de seu convívio e o transportou para o além. Essa decisão de Noé trouxe, na concepção de Hegel, a marca da consciência infeliz, consciência do povo judeu, que apartou o divino do humano.

Na concepção mítica de Eliade, essa atitude de Noé é própria do “homo religiosus que recebe a comunicação dessa história e aceita as suas consequências" (ELIADE, 2013, p. 85). A consequência aqui está pautada numa consciência servil. Para Hegel, esta expulsão do divino para fora do mundo sensível não foi, de modo algum, a fonte de uma liberação diante das potências naturais, mas conduziu, inversamente, a um assujeitamento e a uma submissão dos homens ao divino. Nesse sentido, Deus foi afastado 
Religare, ISSN: 19826605, v.15, n.1, agosto de 2018, p.287-307.

definitivamente dos assuntos terrenos e humanos. Tornou-se habitante do céu, o Todo Poderoso. Nesta esteira, diz Eliade, "a transcendência do Ente Supremo sempre serviu de pretexto para a indiferença do homem em relação a ele "[...] o fato de Deus estar distante justifica todo tipo de negligência, senão de indiferença total" (ELIADE, 2013, p. 88). Esse apontamento de Eliade parece estar presente no pensamento de Hegel, perante a atitude de Noé. Isso justifica o fato de Hegel descarregar "todo o lado negativo do seu juízo sobre a religião da consciência, sobre o judaísmo" (TAYLOR, 2014, p. 537).

No entendimento de Hegel, se Noé tivesse optado por uma reconciliação com a natureza, ao invés de dominá-la, “o povo judeu poderia ter assumido outro caminho; poderia ter superado o seu destino, engajandose na via que o teria levado à reconciliação, à reunificação das relações por ele estabelecidas com a natureza e com o mundo" (THIBODEAU, 2015, p. 4950). Esse caminho - apontado por Thibodeau- foi o caminho que o povo grego escolheu, uma vez que, ao contrário do povo judeu, é o povo feliz da história, pois:

Depois do dilúvio de seu tempo, eles convidaram os homens para retomar sua amizade com o mundo e com a natureza, fazendo-os esquecer, na alegria e no gozo, o sofrimento e a hostilidade. Eles reconstruíram a amizade de paz; eles foram os progenitores das nações belas e se tornaram em sua época a mãe de uma natureza nascida de novo, conservando seu vigor juvenil (HEGEL, 1978, p. 236, tradução nossa).

O caminho que Noé tomou e sua atitude causou a separação entre o homem e a natureza. Dessa experiência do dilúvio resultou, simultaneamente, segundo Hegel, na separação do divino do humano. Dessa maneira, depois do dilúvio, a natureza deixou de ser o lugar misterioso, sagrado e familiar. Essa experiência foi vivenciada pelos judeus como uma dessacralização, como uma desespiritualização da natureza e do mundo. De todo modo, desta dessacralização do mundo sensível, o povo judeu não concluiu pela inexistência do Deus divino e do sagrado. Eles vieram a 
Religare, ISSN: 19826605, v.15, n.1, agosto de 2018, p.287-307.

conceber um Deus totalmente apartado de sua vida cotidiana, diferentemente dos gregos que concebiam seus deuses no cotidiano da vida, ou seja, suas divindades estavam sempre presentes na ação humana.

Essa reflexão que Hegel faz da separação do divino com o humano remete-nos a Eliade, quando cita os Fang da África Equatorial, para expressar a distância que há entre Deus e o homem: “Deus (Nzame) está no alto, o homem embaixo. Deus é Deus, o homem é o homem, cada qual em seu lugar, cada qual em sua casa" (ELIADE, 2013, p. 89). É assim que Hegel compreende o Deus da religião judaica, um Deus separado da realidade humana. Esse Deus, diz Hegel: “o Deus dos judeus, no entanto, é a separação máxima: exclui toda a unificação livre, deixando espaço apenas para a dominação ou a escravidão" (HEGEL, 1978, p. 233, tradução nossa).

\section{Judaísmo e Cristianismo}

Como vimos acima, o fato de ter separado o humano do divino, fez com que o povo que queria ser dominante na ideia fosse dominado na realidade, pois:

Os judeus acreditam que seu deus é o Deus que governa todo o mundo. A Torá não dá muitas explicações sobre porque Deus escolheu os patriarcas e seus descendentes. Ao longo da história, os judeus se perguntam por que Deus os escolheu? Antigos sábios afirmam que não foi Deus quem escolheu Israel, mas os israelitas é que escolheram Deus. Segundo a tradição, Deus ofereceu os mandamentos a todas as nações da Terra, mas só Israel aceitou (O LIVRO DAS RELIGIÕES, 2014, p. 174).

Essa ideia de dominante e dominado, a encontramos no capítulo IV da Fenomenologia do Espírito, mais precisamente no parágrafo 189, no qual Hegel fala de duas figuras opostas da consciência: "uma, a consciência independente para a qual o ser-para-si é a essência; outra, a consciência dependente para a qual a essência é a vida, ou um ser para um Outro. Uma é 
o senhor, outra é o escravo" (HEGEL, 2002, p. 147). Porém, “a consciência infeliz ultrapassa esses dois momentos: reúne e mantém unidos o puro pensar e a singularidade" (HEGEL, 2002, p. 163). O puro pensar é o Imutável (Deus), ao passo que a singularidade (sujeito) é o pensante. Nesse sentido:

A consciência, por assim dizer, apenas caminha na direção do pensar e é o fervor do devoto [AnDenken/Andacht]. Seu pensamento, sendo tal, fica em um informe badalar de sinos, ou emanação de cálidos vapores; um pensar musical que não chega ao conceito, o qual seria a única modalidade objetiva imanente (HEGEL, 2002, p. 164).

Para Hegel, a consciência infeliz é uma espécie de interiorização da relação senhor-servo; trata-se da consciência de uma alma alienada ${ }^{6}$, dividida, na qual a oposição senhor-escravo ocorre dentro de um mesmo eu. Em meio a essa oposição, a consciência aspira tornar-se independente do mundo material, assemelhando-se a Deus, o senhor, um ser puramente espiritual. Essa essência, diz Hegel:

É o Além-inatingível, que foge quando abraçado, ou melhor, já fugiu. Já fugiu, pois, de um lado, é o Imutável que se pensa como singularidade, e assim a consciência nele alcança imediatamente a si mesma; a si mesma, mas como o oposto do Imutável. Em vez de captar a essência, apenas a sente, e caiu de volta a si mesma [...] Assim, de outro lado, não pode apreender o Outro como [algo] singular ou efetivo (HEGEL, 2002, p. 164).

Por conta disso, ela se reconhece na condição de servo, corrompida e prisioneira do mundo material, ou seja, ela procura Deus pelas preces, contudo, ainda não o encontrou, apenas devota buscá-lo. Esse crente da consciência infeliz busca Deus através do trabalho e da autorrenúncia. Entretanto, tal consciência é contraditória, porque sua humildade e renúncia são falsas. Assim, conclui Hegel:

\footnotetext{
6 "Alienação para Hegel é o estágio de desunião que emerge de uma simples unidade e é subsequentemente reconciliado numa unidade superior, diferenciada. Em FE, VI-B, é um paradigma da consciência dilacerada (zerrissene) e do espírito auto-alienado (sichentfremdete). $\mathrm{O}$ indivíduo alienado é um estranho para si mesmo" (INWOOD, 1997, p. 46-47).
} 
Religare, ISSN: 19826605, v.15, n.1, agosto de 2018, p.287-307.

Portanto, embora a consciência renuncie na aparência à satisfação de seu sentimento-de-si, ela a si mesma alcança a satisfação efetiva desse sentimento; pois ela foi desejo, trabalho e gozo, e como consciência ela quis, agiu e gozou. Sua ação de graças, na qual reconhece o outro extremo como essência, e se suprassume - é igualmente seu próprio agir (HEGEL, 2002, p. 165).

Assim, por não encontrar Deus na realidade, ela procura encontrá-lo através dos desejos, do trabalho, dos frutos do seu esforço. E agradece a Ele por ter lhe oferecido a oportunidade de realizar estes atos: "com isso, sentese agraciada e, ao agir sobre o mundo, atribui a Deus o princípio de sua opção, perdendo, desse modo, a satisfação de sua independência e ganhando o sentimento de sua unidade com o Imutável" (VIEIRA e SILVA, 2014, p. 143). Porém, ela não se dá conta que ocorre aqui uma contradição, pois não percebe que esses atos pertencem a ela mesma, pois foi ela quem desejou, trabalhou, gozou.

Sendo assim, mesmo quando ela tenta renunciar esse prazer através do jejum, da mortificação, realiza essa renúncia apenas na aparência, pois uma vez tendo agradecido é porque foi satisfeita por algo, isto é, por ter desejado, trabalhado e gozado. Ao tomar consciência desta realidade, ou seja, de ter se encontrado consigo mesma, ela se dá conta que "seu agir é mesquinho e por isso, recurva sobre si mesma, se tornando tão infeliz quanto miserável" (HEGEL, 2002, p. 169).

Agindo assim, a consciência infeliz entende que encontrou uma inimiga, qual seja, ela mesma. E resolve fazer a última tentativa para se reconciliar com o Divino, tentativa que é propiciada por um mediador, que “representa os dois extremos, um para o outro" (HEGEL, 2002, p. 169), pois ela admite que sozinha não é capaz de se libertar do seu sofrimento, de sua infelicidade. A reconciliação, então, é possível, aos olhos da consciência infeliz através da mediação de um padre (ou qualquer outro servo de Deus). Esse mediador é quem decide o que é correto, justo. Esse mediador, diz Hegel: 
Religare, ISSN: 19826605, v.15, n.1, agosto de 2018, p.287-307.

“enquanto está em relação imediata com a essência Imutável (Deus), desempenha seu ministério aconselhando sobre o que é justo" (HEGEL, 2002, p. 169). Desse modo, em seu esforço para purificar-se, a consciência infeliz volta-se contra o próprio corpo, seu próprio agir, mas, quanto mais ela tenta dominar sua natureza física, mais ainda se sente atraída por ela. E aí, finalmente, ela se coloca nas mãos do mediador, entre ela e Deus. "O mediador agora passa a ser depositário que determina tudo o que é justo e ela é dona de seus atos" (VIEIRA e SILVA, 2014, p. 143).

Dessa forma, a consciência infeliz renuncia à sua liberdade, à sua subjetividade, ao seu eu. Ou melhor, ela pensa conseguir isso. O que acontece, todavia, é a confirmação da sua escolha (escolha individual), do seu caráter. Essa religiosidade, portanto, carece de uma fundamentação mais coerente, que faça com que essa individualidade supere os conflitos que ela mesma fantasiou. Neste processo, o que a consciência infeliz não percebe é que as qualidades desse Deus que ela experimenta são as suas próprias qualidades. Por isso, a consciência infeliz é alienada de si mesma, pois ela põe as suas qualidades essenciais para além do que ela própria é em si mesma. E vendose a si mesma considera-se miserável e insignificante, pois Deus continua além dela. Neste contexto, a consciência-de-si, enquanto consciência infeliz, objetifica-se, tornando-se razão. "Na razão unem-se a consciência e a consciência de si. A certeza é verdade: seria o termo da experiência que a consciência faz de si mesma, pois com a razão a aparência torna-se igual à essência" (MENESES, 2003, p. 34).

Portanto, a consciência infeliz, essa consciência-de-si abstrata, projeta para além de si mesma seu ideal de realização que seria o da unidade dela mesma com a consciência imutável. Contudo, como essa essência imutável reside em um além inatingível e inalcançável, o espírito acaba por buscar uma objetividade sem jamais consegui-la, sobrando apenas a "dor do espírito" (HEGEL, 2002, p. 458) a essa infeliz consciência. 
Religare, ISSN: 19826605, v.15, n.1, agosto de 2018, p.287-307.

Nesse sentido, podemos dizer que a consciência infeliz manifesta-seno cotidiano do ser religioso que luta contra a sua própria autocontradição interna. Hyppolite (1999) diz que: “Toda consciência-de-si é, para si mesma, dupla: ela é deus e o homem no seio de uma única consciência", que projeta para fora de si em uma essência imutável e eterna (Deus). Assim, nosso esforço aqui é tentar entender o que Hyppolite (1999) quer afirmar ao colocar Deus e o homem numa mesma consciência simultaneamente (particularuniversal). Dado isso, Hyppolite argumenta:

Para caracterizar a consciência-de-si, o que precisamos aprofundar é essa íntima cisão do eu. Ser uma consciência de si somente vivente é poder elevar-se à independência, recusar-se à escravidão; tal independência na ordem da vida, porém, se transpõe em liberdade diante da vida (HYPPOLITE, 1999, p. 209).

Essa efetividade da cisão do eu que se projeta num Outro fora de si, na perspectiva de Hegel, manifesta-se na religião do judaísmo na forma de consciência infeliz que concebe o divino num Outro de si. Por isso, Hyppolite afirma que "o judaísmo é a religião do sublime e da separação entre o homem e Deus; rejeita a liberdade além do eu mutável, pondo-a para além do homem" (HYPPOLITE, 1999, p. 207). Segundo Hyppolite, a cultura religiosa judaica promoveu essa consciência cindida e separada, ou melhor, esse paradoxo que procura se elevar da contingência da vida à certeza imutável de si, mas, ao mesmo tempo, em que sobe ao absoluto (Deus), rebaixa-se na consciência do ser-aí mutável (humano) sem essência e longe de si mesma.

Desse modo, a religião judaica separa o ser humano de Deus e rejeita a liberdade do ser humano existente em si. Nesta esteira, afirma Hyppolite: “o senhor e o escravo são, agora, Deus e o homem. Mas, como se admite, se o homem não é sem Deus, inversamente Deus não é sem o homem" (HYPPOLITE, 1999, p. 211). 
Religare, ISSN: 19826605, v.15, n.1, agosto de 2018, p.287-307.

Dentro dessa dinâmica, acerca da separação e da dominação, laçaremos agora nosso olhar para a figura de Abraão que, ao se submeter ao pedido de um Deus totalmente transcendente (Gn 12,1-5), que na concepção de Hegel tornou-se seu escravo. A ruptura feita por Abraão é concebida por Hegel como uma separação, uma vez que ele rompe com os laços da vida e do amor comunal, "não há mais vínculo vivente entre o finito e o infinito. É o que Hegel quer dizer quando escreve: Abraão não sabia amar" (HYPPOLITE, 1999, p. 207). Ao agir assim, diz Hegel:

Ele logo abandonou as florestas [sagradas] que tantas vezes emprestou sombra e frescor; nelas teve teofanias, aparições de seu objeto supremo, no entanto, não voltou a amá-las como algo sagrado, digno de sua divindade, tendo participado dela mesma (HEGEL, 1978, p. 288, tradução nossa).

Nesse sentido, as relações de outrora perderam seu caráter sagrado e o homem passou a ser dominado pela vontade humana. Assim, a natureza se tornou, para Abraão, uma matéria bruta que não podia ser unida pelo espírito, mas devia ser dominada por ele. Por esta razão, podemos ler em Hegel:

O Deus de Abraão não era um membro da família, como o Deus que tiveram outros povos, no sentido de que a nação judaica deve ter sido a única nação. Abraão, completamente isolado do mundo inteiro, de toda a natureza, queria dominar sua família acima de todas as coisas; mas seu pensamento era contrário à sua realidade, e porque era limitado, apenas entrou em sua vida, em vez de ir para fora do caminho. A partir disso, a dominação se tornou seu ideal. Nele a opressão unificava o todo. Abraão era um tirano em sua mente; seu ideal realizado, Deus: algo que não participava do mundo, mas estava dominado por ele (HEGEL, 1978, p. 229, tradução nossa).

Essa dominação, da qual fala Hegel, presente na consciência de Abraão, de forma alguma foi conferida ao ser humano por Abraão, mas tencionada por Deus (cf. Gn 12). Nesse sentido, afirma Taylor: 
Religare, ISSN: 19826605, v.15, n.1, agosto de 2018, p.287-307.

Os seres humanos só têm parte nessa unidade pura em oposição à natureza apegando-se a Deus, e para esse fim o povo escolhido deve separar-se rigorosamente de outros povos e dos Deuses da natureza. Porém, entregar-se a um Deus de Herrschaft (dominação) é submeter-se à sua vontade, é tornar-se seu escravo (TAYLOR, 2014, p. 82).

No pensamento de Hegel, essa estrutura aparece na dialética do "senhor e do escravo" (HEGEL, 2002). Nisso consiste o que Hegel chama de consciência infeliz; a consciência da separação da natureza; a consciência em que a unidade e a mutualidade são substituídas pela dominação e a servidão. Segundo ele, esse distanciamento, essa separação só podia levar a "relações de dominação e servidão. A separação da natureza confronta-nos com a escolha de dominá-la ou sermos dominados por ela, e a separação entre o espírito e nós mesmos como seres naturais converte-nos em escravos de Deus" (TAYLOR, 2014, p. 84). Acerca disso, afirma Hegel:

O mesmo espírito que afastou Abraão de sua tribo o guiava em meio aos seus encontros com outras nações durante o resto de sua vida: o espírito de autoconservação imóvel, que mantinha por meio de uma estreita oposição contra todas as coisas; o resultado desse pensamento foi a condição de unidade dominante acima da natureza, que ela via como infinita e hostil, pois a única relação entre entidades hostis é a dominação de uma pela outra (HEGEL, 1978, p. 287-288, tradução nossa).

Dessa maneira, a religião do judaísmo caminha de forma oposta ao mundo grego, que amava a natureza em si, a família e os povos, sendo uma consciência do infinito nas singularidades das coisas. Por isso, o povo grego é considerado o povo feliz da história, pois neles não há um rompimento com a natureza, com a pátria e a família.

Hegel afirma com isso, segundo Hyppolite, que a religião do judaísmo põe a essência fora da existência, pois ao tomar consciência de sua dualidade, coloca-se sempre ao lado do sem essência, passando a ser um nada, e seu existir uma transcendência. Entretanto, o ser humano, ao perceber que sua 
Religare, ISSN: 19826605, v.15, n.1, agosto de 2018, p.287-307.

essência não está em si mesma, procura libertar-se dessa realidade, unindo forças para atingir o ser para si. Visto que na religião do judaísmo Deus é concebido como um senhor inacessível e o ser humano é escravo, isso está de acordo com o que encontramos no parágrafo 197 da Fenomenologia do Espírito (2002) e, segundo Hyppolite, "essa categoria histórica do senhor e do escravo se transpõe em categoria religiosa" (HYPPOLITE, 1999, p. 213).

Neste contexto, vê-se que o manifestar da consciência de si independente desdobra-se numa consciência dada apenas em um eu abstrato e, por mais que consiga cultivar algo, ou perceber as diferenças, ainda assim não é essência para si, pois o objeto não coincide em si, consigo mesmo e, por isso, a consciência escrava não atingiu a consciência independente. Entretanto, para Hegel, a consciência se manifesta como conflito dialético do ser humano que está em busca de sua unidade. Diante disso, podemos ler em Hyppolite:

A consciência infeliz é a subjetividade que aspira ao repouso da unidade, é a consciência-de-si como consciência da vida e daquilo que supera a vida, mas não pode senão oscilar entre os dois momentos, como inquietude subjetiva que não encontra em si sua verdade e a reflexão de si - reflexão da vida - aparece-nos, como a elevação à liberdade (HYPPOLITE, 1999, p. 210).

Esta análise demonstra como podemos considerar a experiência religiosa da consciência dentro da religião do judaísmo a partir da dialética do senhor e do escravo na forma de consciência infeliz que, ao experimentar Deus fora de si, continua sendo infeliz. Foi, portanto, "essa escolha que levou o povo judeu a curvar-se sob um Deus infinitamente potente e dominador, sob uma divindade transcendente e exterior à qual eles consentem submeterse e assujeitar-se servilmente" (THIBODEAU, 2015, p. 49). 
Religare, ISSN: 19826605, v.15, n.1, agosto de 2018, p.287-307.

No contexto da Fenomenologia do Espírito, Hegel não aborda diretamente o conteúdo da religião judaica7. No entanto, procura apontar o limite do antropomorfismo grego, pois a unificação do divino com o humano acontece tanto na religião grega quanto no cristianismo. Na religião grega, “a consciência religiosa vê seu ideal perfeitamente realizado no próprio ser humano por meio das produções artísticas" (THIBODEAU, 2015, p. 139) e, no cristianismo, na pessoa de Cristo. Já o judaísmo vê “Deus totalmente separado do ser humano" (TAYLOR, 2014, p. 236). Esse dado encontramos no início da análise da obra de arte viva, na Fenomenologia do Espírito (2002), na qual Hegel faz uma comparação entre a religião grega e a religião judaica:

O povo, que no culto da religião da arte se aproxima do seu Deus, é o povo ético que sabe seu Estado e suas atuações do Estado como a vontade e o desempenho de si mesmo. Esse espírito, que contrasta com o povo consciente de si, não é, pois, a luminosidade, que sendo carente de si, não contém em si a certeza dos singulares, mas antes, é apenas sua essência universal, e a potência do senhor, onde os singulares desvanecem. O culto da religião dessa essência simples e sem figura, em geral só dá a seus fiéis o retorno de serem o povo do seu Deus. Só lhes assegura sua subsistência e sua substância simples em geral, mas não seu ser efetivo, que antes é rejeitado. Pois veneram seu Deus como profundeza vazia, e não como espírito (HEGEL, 2002, p. 485).

Percebemos aqui, então, que falta na religião judaica o momento em que o espírito olhe para si mesmo. Nela, o espírito alcança a falta de forma, ou seja, Deus está fora do ser humano. Essa representação judaica de Deus não permite que o ser humano alcance a certeza de si mesmo e, isso, por conta da transcendência absoluta de Deus. Assim, "pelo fato de esse Deus realmente estar além e não ser capaz de unir-se com os seres humanos, pertencer a ele continua representando servidão" (TAYLOR, 2014, p. 538). "Sereis para Mim uma propriedade peculiar entre todos os povos" (cf. Ex

\footnotetext{
7 Devido a essa ausência, do conteúdo da religião judaica na Fenomenologia do Espírito (2002), é que recorremos as interpretações de Jean Hyppolite (1999).
} 
Religare, ISSN: 19826605, v.15, n.1, agosto de 2018, p.287-307.

19,5). Isso aparece até mesmo nas palavras do próprio Hegel: “o Deus ciumento de Abraão e seus descendentes possui em si uma horrível afirmação de que só ele era Deus e que esta nação era a única que tinha um Deus" (HEGEL, 1978, p. 289, tradução nossa).

Na religião grega, os deuses colocam-se próximos aos seres humanos. Ela é "a bela unidade do ser humano com Deus" (TAYLOR, 2014, p. 538). Para o povo judeu, porém, isso não vale, pois seu modo de representar Deus apenas assegura sua permanência transcendental. Esta é a religião da lei e da servidão. Assim, citando Hegel, Plant considera:

Com seus rebanhos, Abraão perambulou de cá para lá num território desprovido de fronteiras sem tornar partes dele mais próximas de si, cultivando-as ou melhorando-as... Ele era um estrangeiro tanto ao solo quanto aos homens... Abraão olhava o mundo inteiro como seu oposto; se ele não o tomava como uma nulidade, considerava-o sustentado por um Deus que era alheio a ele. Nada na natureza era considerado tendo parte em Deus; tudo estava simplesmente sob o domínio de Deus (PLANT, 2000, p. 21).

Esse pensamento nos leva à ideia da dicotomia entre o finito e o infinito. Nesse sentido, “a consciência do infinito é então acompanhada pela consciência da finitude, e toda existência está reduzida a um ser-aí finito" (HYPPOLITE, 1999, p. 207). Desse modo, na religião judaica, a consciência de si do espírito é presente para a consciência com a limitação de ser uma universalidade abstrata, o que em parte deve-se ao fato de que o Deus de Abraão, Isaac e Jacó seja apenas um Deus de sua própria pátria, ou seja, restrito somente a este povo.

Para Hegel, o fato de esse povo ter recebido o território como herança $($ Gn 17,8$)$ implica uma posse que não pode ser modificada. Segundo Hegel, a restrição do espírito do judaísmo será a incoerência que reside no fato de que o espírito, os seus mandamentos, tanto os religiosos quanto os cultuais, firmam-se em uma ordem perene e inabalável desse Deus que a consciência 
Religare, ISSN: 19826605, v.15, n.1, agosto de 2018, p.287-307.

experimenta de modo contemplativo. A construção cultual e política são ensinamentos desse Deus abstrato. Assim, "a constituição judaica, a legislação política do povo judeu é, de início e antes de tudo, de natureza teocrática: seu conteúdo não concerne à organização da vida política dos cidadãos, mas visa a, essencialmente, organizar e determinar o culto e o serviço divino" (THIBODEAU, 2015, p. 45). "Andarão de acordo com as minhas normas e guardarão os meus estatutos e os praticarão" (cf. Ez 37,24). Por isso, afirma Hegel: "os judeus são totalmente dependentes de Deus" (HEGEL, 1978, p. 295, tradução nossa).

Olhando para esse quadro, vemos que a experiência religiosa que a consciência faz no judaísmo, consegue avançar até o ponto em que o ser humano, pelo espírito e pelo conhecimento do universal (Deus) e do particular (homem), engloba o próprio Deus. Contudo, Deus é a causa de tudo isso, Deus é quem dita as regras, e não o ser humano, ou seja, Deus continua fora dele. Por isso, Hegel afirma: "posto que os judeus como cidadãos eram nada, pois adquiriram valor apenas por meio de seu relacionamento com Deus, era necessário que vinculassem o máximo possível os seus atos com a religião" (HEGEL, 1978, p. 232, tradução nossa). Na mesma esteira também Hippolite considera: "no judaísmo, o homem se experimenta como nada: é o pensamento de toda finitude, e Deus permanece necessariamente um além jamais atingido, a única negação do finito" (HYPPOLITE, 1999, p. 207).

Neste caso, a consciência religiosa não se satisfaz plenamente, pois a satisfação da reconciliação ainda não existe para a religião judaica, visto que Deus está ainda para além dela. Segundo Taylor, há um grande “abismo entre ser humano e Deus" (TAYLOR, 2014, p. 236). Neste contexto, o que a consciência experimenta é a dor de si mesma, sua satisfação é constituída de finitas satisfações que se efetivam na família (terá uma nação numerosa) e na posse da terra (uma terra que corre leite e mel), mas em Deus mesmo a consciência não consegue se satisfizer. 
Religare, ISSN: 19826605, v.15, n.1, agosto de 2018, p.287-307.

Na religião judaica, a identidade do sujeito com Deus é o conhecimento de Deus em sua verdade, sendo que o conteúdo dessa verdade é o próprio espírito, o movimento vivo em si. Contudo, Hegel observa que a natureza de Deus, o puro espírito em si, manifesta-se apenas com a concretização do conceito de religião, que será a religião manifesta, na qual o espírito será colocado perante o seu outro e retornará em si mesmo. Assim, a identidade entre o homem e Deus, segundo Hegel, não vem ao mundo com a religião judaica, mas somente com a religião manifesta, o cristianismo, no qual "a natureza divina será a mesma que a humana" (HEGEL, 2002, p. 510).

Embora, o povo judeu fosse considerado por Hegel como sendo o povo infeliz da história, ele considera-o uma fase indispensável para a chegada do cristianismo, tal como atesta Taylor:

O judaísmo preparou o caminho para a Encarnação, em que a inteira sublimidade de Deus, sem esperança de qualquer união com o ser humano, vem, em última análise, para ser vivida em forma de sofrimento, um sofrimento em que o ser humano sente a sua separação à base essencial das coisas, uma espécie de ausência total do próprio fundamento. Esse sofrimento clama por um salvador, pela vinda de Deus para dentro do ser humano (TAYLOR, 2014, p. 537).

Nessa ideia, de que Deus assume a condição humana, reside a reconciliação da dor e da infelicidade humana em si, considerando que "na base desse estudo hegeliano encontra-se a copiosidade de suas reflexões sobre o desenvolvimento histórico do judaísmo e do cristianismo" (TAYLOR, 2014, p. 188). Contudo, mesmo o cristianismo não será capaz de reconciliar-se definitivamente com Deus, pois a experiência religiosa dessa religião (cristianismo), ainda continua oscilando entre o além e o aquém. Trata-se, portanto, de uma reconciliação intermitente e nunca definitiva. 
Religare, ISSN: 19826605, v.15, n.1, agosto de 2018, p.287-307.

\section{Conclusão}

A partir da análise da experiência religiosa da religião do judaísmo, vemos que Deus enquanto espírito separado do humano não pode ser o fim último para a morada do divino. Como vimos, a consciência infeliz se define como separação do homem com Deus, buscando sua essência sempre além de si mesma, isto é, no transcendente. Contudo, no cristianismo, há uma mudança radical, pois Deus (ser) do além se manifestou para o homem (ser) do aquém. Desse modo, a consciência infeliz nesse momento não se fixa nos polos do além ou da consciência em si, mas agora descobre-se como movimento que busca ultrapassar essa dualidade oposta em si, visto que, para o cristianismo, Jesus é Deus, havendo assim uma identidade entre ambos, sendo que Cristo, feito homem, possui as duas naturezas: humana e divina.

Nesta ótica, percebe-se que a consciência quer se superar a si mesma, quer se libertar do seu nada, pois o imutável (Deus) só é possível na consciência singular (homem), como o exemplo da encarnação do Cristo histórico (Deus se tornou homem). Nesse sentido, o imutável - aquele que estava além - não é mais somente transcendente, mas está agora unido também ao ser imanente, e é nesse momento que podemos fazer uma interpretação estritamente deísta ao dizer que "a unidade se produz para essa consciência - unidade do Universal e do Singular, da consciência imutável e da consciência mutável - tal unidade é a encarnação de Deus, a figura do Cristo histórico" (HYPPOLITE, 1999, p. 216). Com efeito, conforme já havia sido dito no início da presente reflexão, partindo das palavras de Hyppolite, “o povo judeu era o povo infeliz da história porque representava a reflexão total da consciência fora da vida" (HYPPOLITE, 1999, p. 206). Entretanto, somente no cristianismo Deus estará intimamente unido com o humano, visto que no judaísmo Ele está separado, está para além do humano. 
Religare, ISSN: 19826605, v.15, n.1, agosto de 2018, p.287-307.

\section{Referências}

BIBLÍA DO PEREGRINO. São Paulo: Paulus, 2002.

ELIADE, Mircea. Mito e realidade. Trad. PolaCivelli. São Paulo: Perspectiva, 2013.

COULIANO, Ian e ELIADE, Mircea. Dicionário das religiões. São Paulo. Martins Fontes, 1994.

HEGEL, Georg Wilhelm Friedrich. Fenomenologia do Espírito. Trad. Paulo Meneses. 3. ed. Petrópolis: Vozes e Editora Universitária São Francisco. Bragança Paulista, 2002.

. Escritos de juventud. Trad. Zoltanszankay y José María Ripalda. México. Fondo de Cultura Económica, 1978.

HYPPOLITE, Jean. Gênese e estrutura da Fenomenologia do Espírito de Hegel. São Paulo: Discurso, 1999.

INWOOD, Michael. Dicionário Hegel. Trad. Álvaro Cabral. Rio de Janeiro: Jorge Zahar, 1997.

KÜNG, Hans. Religiões do mundo: Em busca dos pontos comuns. Trad. Carlos Almeida Pereira Campinas: Verus, 2004.

MENESES, Paulo. Hegel e a Fenomenologia do Espírito. Rio de Janeiro: Jorge Zahar, 2003.

O LIVRO DAS RELIGIÕES. Trad. Bruno Alexander. 1. ed. São Paulo: Globo Livros, 2014.

PLANT, Raymond. Hegel, sobre religião e filosofia. Trad. Oswaldo Giacóia Jr. São Paulo. UNESP, 2000.

TAYLOR, Charles. Hegel: sistema, método e estrutura. Trad. Nélio Schneider. São Paulo: É Realizações, 2014.

THIBODEAU, Martin. Hegel e a tragédia grega. Trad. Agemir Bavaresco e Danilo Vaz-Curado. São Paulo: É Realizações, 2015.

VIEIRA, Leonardo Alves e SILVA, Manuel Moreira (orgs.). Interpretações da Fenomenologia do Espírito de Hegel. São Paulo: Loyola, 2014. 